\title{
Granulated blast furnace slag - A boon for foundry industry
}

\author{
I. Narasimha Murthy ${ }^{1}$, N. Arun Babu ${ }^{2}$ and J. Babu Rao ${ }^{1}$ * \\ ${ }^{I}$ Dept of Metallurgical Engg, Andhra University, Visakhapatnam - 530003, INDIA \\ ${ }^{2}$ Dept of Mechanical Eng., Khammam Institute of Technology \& Sciences, Khammam - 507170, INDIA \\ *Corresponding author's Email: baburaojinugu@yahoo.com \\ *Phone Number: +919848431073
}

\begin{abstract}
In the present investigation efforts have been put together to employ Granulated Blast furnace (GBF) slag as mould material for replacement of existing silica sand either full or partial in foundry industry. Nishiyama procedure was assumed for appraising the same. The process factors reflected on for this were the \% of sodium silicate, $\%$ of Fe-Si powder and mould setting time. A sequence of tests on sand was conducted on sand, slag as per American foundry society standards. Two categories of moulds were built by means of sand and slag independently with optimum process parameters. A356 alloy and grey cast iron castings were executed on these recently built up slag moulds. The outcomes show that the mould's compression, permeability as well as the shear strength of the GBF slag is an appropriate candidate for either incomplete or complete substitute of moulding sand. At some point in casting, the absence of fusing, dripping or mould wall collapse walls was noticed; this is exact for the ferrous as well as non-ferrous castings. Castings exhibiting high-quality surface finish, absence of surface defects as well as porosity were created by slag moulds.
\end{abstract}

Keywords: Silica sand; Blast Furnace Slag; Mould properties; Ferrous and nonferrous castings.

\section{Introduction}

Silica sand is the essential raw material for the production of cast components in foundry industries. The growing demand of sand results in non-availability of good quality sand and deposits of natural sand are being exhausted which create an extreme menace to the environment. To safeguard the environment, efforts are being made for using industrial waste in foundry applications for conserving natural resources and reduce the cost of the raw materials (Al-Jabri et al., 2009; Kothai and Malathy, 2014; Dash et al., 2016). The blast furnace (BF) slag is a manufacturing dense waste produced from the process of iron and steel manufacturing. An excess of 10 million tons of slag from the blast furnace is created in India alone on an annual basis. This is referred to as a by-product of iron and steel manufacturing. It is perceived that the created BF slag which in huge quantities is dumped in the dump yard and only half of the quantity is used for production of cement and for laying roads (Svyazhin et al., 1998).

Considering the huge amount of slag ease of use, exhibiting comparable physical as well as chemical characteristics together with silica sand the BF slag can be used as a moulding material in foundry industry. Hence, the present examinations are resolute to appraise the appropriateness of BF slag as a new mould material in ferrous as well as non-ferrous foundries. Exothermic self hardening process named as Nishiyama process (or) Fe-Si process was used for the same. This process comprises the mixing of sodium silicate and ferrosilicon powder with mould ingredients. The mould is hardened and bonded with the reaction product obtained by exothermic reaction between sodium silicate and ferro silicon powder. This reaction takes place all the parts of the mould simultaneously which lead to uniform hardening throughout the mould, and this is achieved without a gassing operation. The contemplated parameters of the process in this research were \% of Sodium silicate, \% Fe-Si powder and mould hardening time. 


\section{Materials and Methods}

The choice of materials in the current research was restricted to two kinds, notably the elevated silica sand as well as the granulated blast furnace (GBF) slag. The silica sand has significant importance in practice as sand for moulding, employed in the foundry industries. The source of procurement of silica sand in this work is Chirala, located in Andhra Pradesh at the southeastern coast, India. The slag from the blast furnace in the form of granulation i.e. sodium silicate as well as ferro-silicon was purchased from a company known as the Visakhapatnam Steel Plant in Visakhapatnam in India. Ferro silicon is further converted from lumps to powder form to 35 micron size and added as a binder material for mold making. At about $300^{\circ} \mathrm{C}$ and in a period of 3 hours, the preheating of the silica sand as well as the granulated blast furnace slag (GBF) particulates was conducted. The equipment used is the muffle furnace. The aim was to dispose of every moisture occurence in them. Later on these materials were investigated for their chemical and physical properties. Figure 1 reveals the sand as well as the slag particles employed for the current research. The physical, chemical and thermal properties of silica sand and GBF slag were analyzed and same was presented in earlier publication (Murthy and Rao, 2016). The summary of the some of the properties was given in Tables $1 \& 2$.
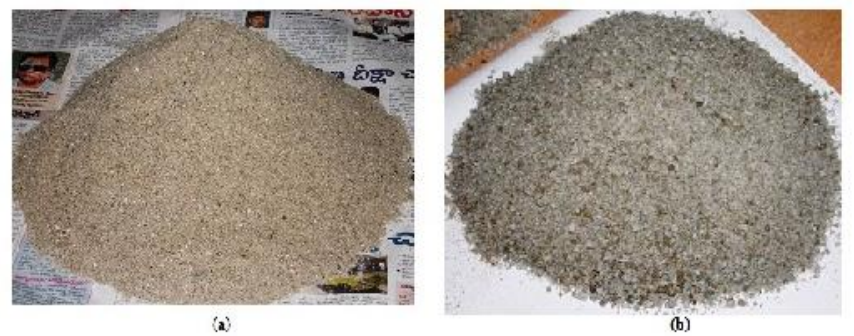

Figure 1: Materials employed for the research: (a) Silica sand (b) GBF Slag

Table 1: The content of silica sand and GBF Slag, wt \% from chemical perspective

\begin{tabular}{|c|c|c|c|c|c|c|c|c|c|}
\hline Material & $\mathrm{SiO}_{2}$ & $\mathrm{CaO}$ & $\mathrm{FeO}$ & $\mathrm{Al}_{2} \mathrm{O}_{3}$ & $\mathrm{MgO}$ & $\mathrm{MnO}$ & $\mathrm{Cr}_{2} \mathrm{O}_{3}$ & $\mathrm{TiO}_{2}$ & $\mathrm{CaS}$ \\
\hline Silica Sand & 96.62 & 0.57 & 1.02 & 1.54 & 0.57 & - & - & - & - \\
\hline GBF Slag & 34.23 & 34.34 & 0.37 & 18.92 & 9.67 & 0.34 & - & 0.72 & 1.46 \\
\hline
\end{tabular}

Table 2: Physical properties of the Chirala Silica Sand and Granulated Blast furnace slag

\begin{tabular}{|c|c|c|c|c|}
\hline \multirow{2}{*}{ S. No } & \multirow{2}{*}{ Material } & \multicolumn{2}{|c|}{ Physical Properties } \\
\cline { 3 - 5 } & & Grain Fineness Number (GFN) & $\mathrm{P}^{\mathrm{H}}$ & Density (gm/cc) \\
\hline 1 & Sand & 35.19 & 7.95 & 2.61 \\
\hline 2 & \multirow{2}{*}{ GBF Slag } & 24.40 (As received condition) & 11.40 & 1.52 \\
\cline { 3 - 5 } & & 35.65 (After processing) & \\
\hline
\end{tabular}

\subsection{Standard Specimen preparation}

A typical sample test of a cylindrical shape containing sand as well as GBF slag was organized as indicated by the AFS (American Foundry Society) criteria through the employment of sand rammer. The diverse parameters for the process considered in the work are listed subsequently: mould set-up time, $\%$ of Fe-Si powder and \% of Sodium silicate. Broadly, for silica sand moulds of Fe-Si process, the percentage of sodium silicate and $\mathrm{Fe}-\mathrm{Si}$ powder will be used in the range of 2-6\% and 0.5 to $2 \%$ respectively (Bo et al., 1995); for this reason, the same array was selected for the current research to assess and obtain the most advantageous the mould properties for the two choice materials - slag and the silica sand.

The mould material was blended with the aid of a blender, muller, a laboratory-scale representation by Ridsdale and Co. Ltd. It has a serial No. of 845. In every batch, a kilogram of ingredients for the two mould, that is silica sand as well as the particles of slag were used individually while separate investigations were conducted for the diverse proportions of these two blends. Predetermined quantities of sodium silicate and $\mathrm{Fe}$-Si powder were added to the mould ingredients; blending was conducted in a timeframe of five minutes. Typical test samples of $50 \mathrm{~mm} \mathrm{X} 50 \mathrm{~mm}$ size were created through the employment of sand rammer. Many samples were created were prepared for in-depth study of diverse mould characteristics. The prepared samples were allowed for self hardening in ambient atmosphere at room temperature for the duration of 24 hours. Every two hours the mould properties were analyzed and same was reported. Figure 2 reveals the typical specimens of GBF slag and silica sand, correspondingly. 


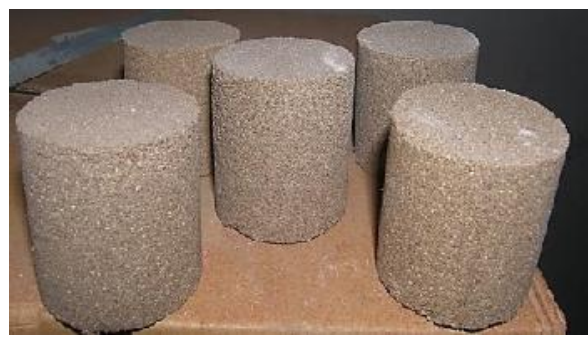

(a)

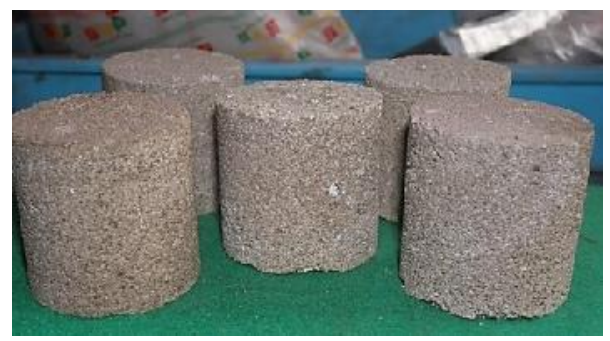

(b)

Figure 2: Shows the standard samples of: (a) 100\% Silica Sand (b) 100\% GBF Slag and

\subsection{Mould properties evaluation}

The specimens after self hardening at different time intervals up to 24 hours were examined to appraise the diverse mould characteristics, such as compression, permeability, shear strength and hardness. Typical testing process was adhered to for every examination. A mean three specimen reading was measured to account for the relevant characteristics. Optimum mould properties were evaluated with various combinations of sodium silicate and Fe-Si additions in slag and sand moulds.

\subsection{Melting and Casting practice}

Melting as well as casting preparations of the ferrous as well as non-ferrous castings was conducted using the novel GBF slag moulds in evaluating the thermal stability and also the stability due to physical means for the slag as well as sand moulds. With special reference to the current research, the Type 1 as well as Type 2 moulds was chosen. While Type 1 consists of $100 \%$ silica sand, the composition of Type 2 is 100\% GBF slag. The most advantageous properties of the mould were attained through adding $10 \%$ sodium in conjunction with $2 \% \mathrm{Fe}-\mathrm{Si}$ for GBF slag. Furthermore, for the sand mould, $6 \%$ sodium silicate was added with $1.5 \% \mathrm{Fe}-\mathrm{Si}$. These ready-to-use moulds were created for casting the ferrous as well as non-ferrous materials. While A 356 (Al-Si) alloy was selected for non-ferrous casting, the gray cast iron was selected for the ferrous casting. Two types of patterns namely toothed gear wheel and connecting rod were chosen and aimed to cast the same. The cope and drag as well as split pattern was employed to create the mould having a mould cavity. Approximately $500 \mathrm{~g}$ ingot weights for each material were employed in a graphite crucible while being melted individually in an elevated temperature melting furnace with temperature values of 750 to $1400{ }^{\circ} \mathrm{C}$ for Al-Si alloy (A356) as well as gray cast iron, correspondingly. The molten metal was permitted to load the mould cavities through sprue, runner as well as in-gates; caution was taken in ascertaining constant and level liquid metal flow as the loading of the mould cavities progress. Riser was positioned in the mould, ascertaining total mould cavity filling. The castings were extracted from the boxes (moulds) following cooling while further activities of quality inspection were done on them.

\section{Results and Discussion}

\subsection{Particles bonding studies through SEM}

Figure 3 (a \& b) shows the SEM images of grain surfaces and a bonding bridge developed by sodium silicate with Fe-Si Powder as binder for Sand and GBF slag moulds respectively. In Fe-Si process, silica sand is hardened and bonded with the reaction product obtained by exothermic reaction between sodium silicate and ferro-silicon powder; it will led to improvement of wettability of grain particles (adhesion) and strengthening of binder bridges (cohesion), which allowed to harden the grains interface. This figure also shows the binding bridges between the particles of sand and GBF Slag in respective moulds. During curing process, sodium silicate glass coating was observed around the particles and forms bridges at the contact between the particles with foaming action around it, which can be clearly visible from the obtained SEM images of the moulds under investigation, Figure 3 (a \& b).

In this process sodium silicate and Fe-Si powder are blended using a ratio of weights as 2.25:1. The presence of these two in the mould foaming accomplishment happens as well as the temperature grows concurrently, attaining a situation for boiling at roughly $90^{\circ} \mathrm{C}$. In the course of the chemical accomplishment, steam as well as hydrogen is liberated. The occurring reactions are (ASM Handbook, 2008; Stachowicz et al., 2010):

$$
\begin{aligned}
& \mathrm{Na}_{2} \mathrm{O}_{\mathrm{n}} \mathrm{SiO}_{2}+\mathrm{H}_{2} \mathrm{O} \rightarrow \mathrm{SiO}_{2}+2 \mathrm{NaOH} \\
& 2 \mathrm{NaOH}+\mathrm{Si}+\mathrm{H}_{2} \mathrm{O} \rightarrow \mathrm{Na}_{2} \mathrm{O} . \mathrm{mSiO}_{2}+2 \mathrm{H}_{2}
\end{aligned}
$$

It observed that the equilibrium of reaction (1) is disturbed by the presence of silicon, leading to reaction (2) with the result that the mixture is hardens. This effect persists on the condition that silicon as well as water exists. If silicon is added more approximately 
every water occurring is dispersed through decomposition as well as evaporation. This effect is slow at the room temperature condition. However, as the temperature is stepped up, the effect increases while at the end the products of effect yield a solid soft mass.

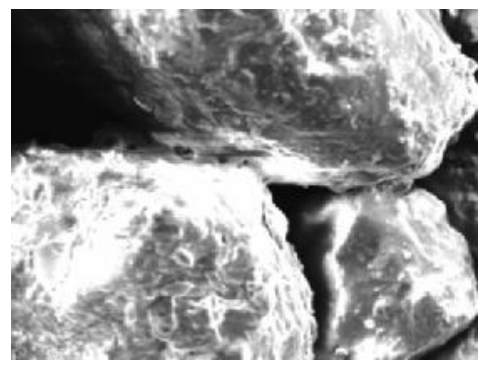

(a)



(b)

Figure 3: SEM images of grain surfaces and a bonding bridge developed by sodium silicate with $2 \% \mathrm{Fe}-\mathrm{Si}$ : (a) $100 \%$ Sand (b) $100 \%$ GBF slag

\subsection{Evaluation of Sand and GBF Slag mould properties}

Figures 4-7 shows the mould properties of silica sand and GBF slag respectively with various combinations of sodium silicate and $\mathrm{Fe}-\mathrm{Si}$ additions at 24 hours mould setting time. For sand moulds as per the existing Fe-Si practice, the sodium silicate was varied from 2-6\% with various combinations of $\mathrm{Fe}-\mathrm{Si}(0.5-2.0 \%$ with interval of $0.5 \%)$. To obtain the more or less similar of sand mould properties in GBF slag different combinations of sodium silicate and $\mathrm{Fe}-\mathrm{Si}$ were examined. However, it was finally concluded to achieve same properties with the Sodium silicate and $\mathrm{Fe}-\mathrm{Si}$ additions in the range of 8-12\% and $0.5-2.0 \%$ (with intervals of $0.5 \%$ ) respectively. These figures illustrate the clear and very well distinguished mould properties of hardness, compression, shear strength and permeability values for all the materials under investigation. In case of sand, enhanced mould properties like mould hardness, compression and shear strengths were obtained for lower Fe-Si content (up to 1.0\%); these mould properties were further enhanced with higher sodium silicate additions. For above 1.0\% Fe-Si interestingly decreased mould properties were noticed; this observation was true for all the sodium silicate additions, as shown in Figures 4 (a), 5 (a) and 6 (a). This might be due to with increase of Fe-Si powder the mould curing reaction continues and almost all the water present in the mould is dispelled by decomposition and evaporation; hence mould becomes wet and leads to decrease in mould properties (Dańko et al., 2013; LaFay, 2015).

Interestingly, slag moulds also show rising mould properties with increasing Fe-Si content. This increase was further high for higher sodium silicate additions up to10\%; later it was dropped for 12\% sodium silicate, as shown in Figures 4 (b), 5 (b) and 6 (b). This might be due to higher sodium silicate with more Fe-Si addition lead to wetting of the mould hence lower mould properties. One more interesting observation was GBF slag moulds show slow pick up of the mould properties as compared to sand moulds. As anticipated lower permeability values were obtained with increase in $\mathrm{Fe}-\mathrm{Si}$ addition up to $2 \%$ for both the moulds under investigation; this decreasing trend was further suffered with higher sodium silicate additions (Figure 7 (a\& b)); this might be due to the more closure of the pores for higher binder additions. However, slag moulds shows more or less similar permeability values with silica sand moulds.

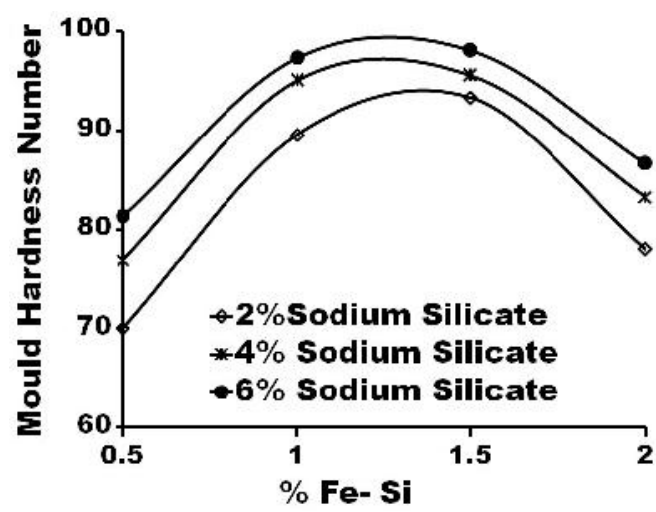

(a)

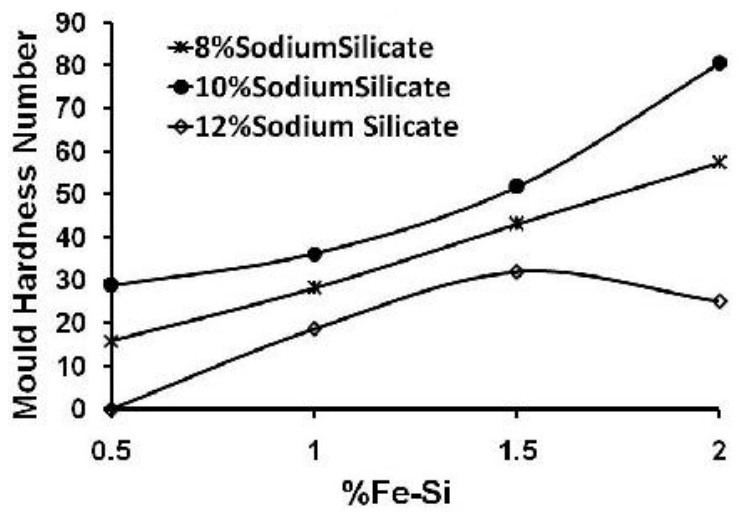

(b)

Figure 4: Comparative mould hardness properties of: (a) 100\% Sand (b) 100\%GBF Slag 


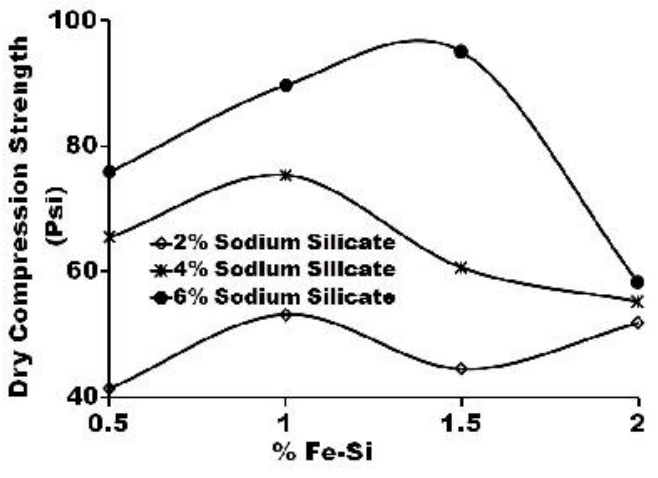

(a)

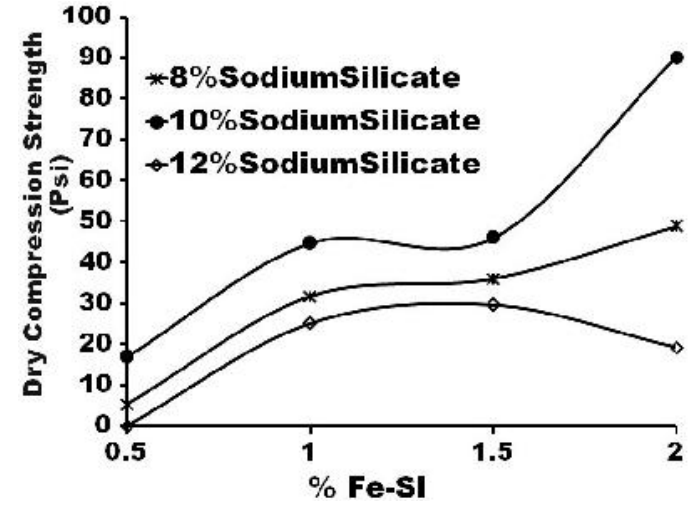

(b)

Figure 5: Comparative mould Compression Strength of: (a) 100\% Sand (b) 100\%GBF Slag

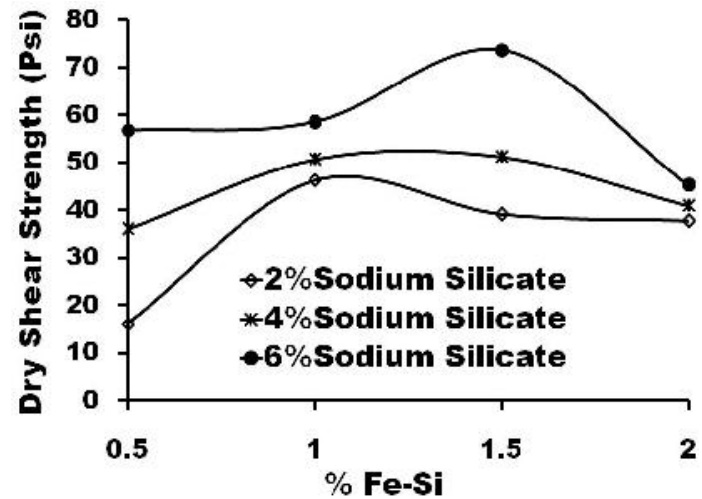

(a)

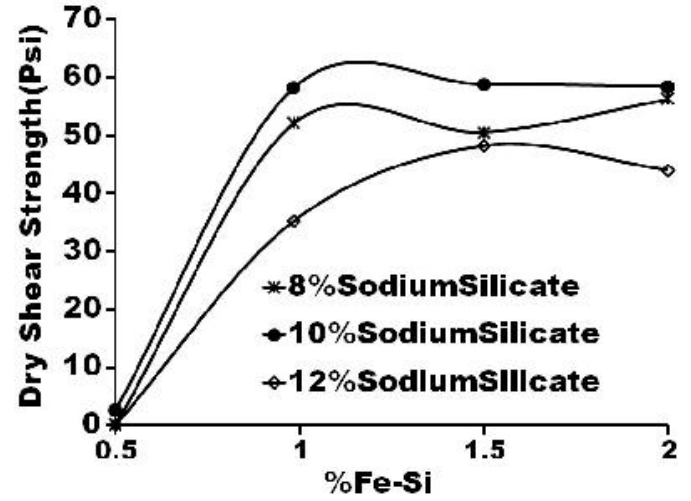

(b)

Figure 6: Comparative mould Shear Strength of: (a) 100\% Sand (b) 100\%GBF Slag

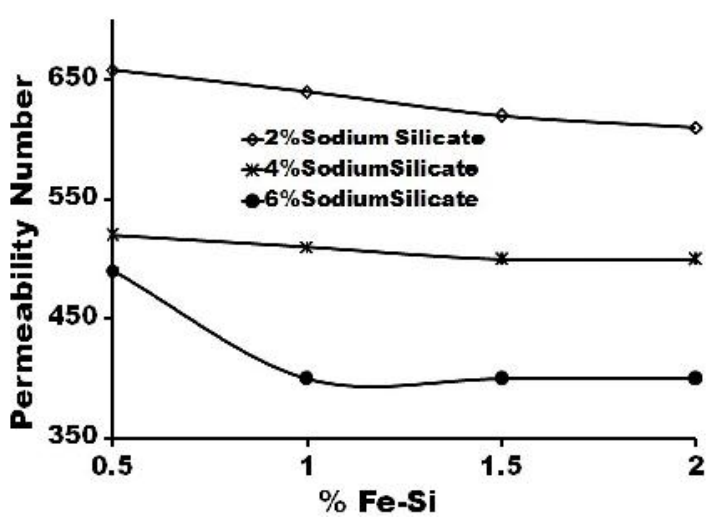

(a)

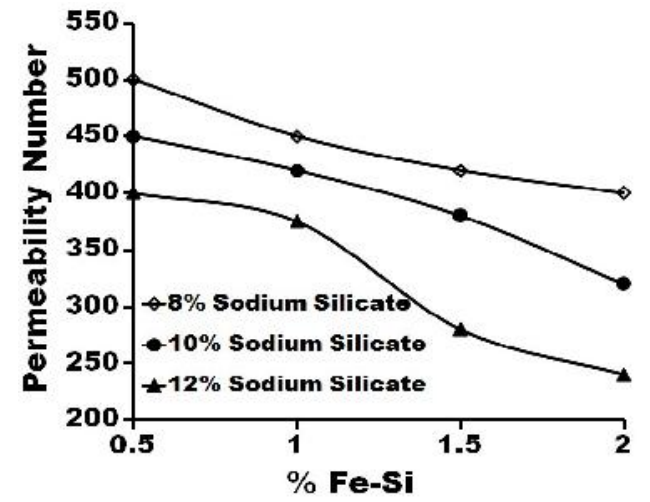

(b)

Figure 7: Comparative mould Permeability of: (a) 100\% Sand (b) 100\%GBF Slag

Additional investigations were conducted to appraise how stable the slag mould properties are considering the bench life; and a similar thing was noted for every two hours time intervals up to 24 hours. The obtaned results were shown in table 3 . Amusingly, all the mould properties shows substantial growing trend over a period of mould bench life; later these were stabilized and same values were retained even after 24 hours duration. Incase of permeability, for prolonged times both sand and slag moulds shows slightly decrseasing trend; however this value was well below the accepted range for both ferrous and non ferrous castings. In conclusion, even after prolonged duration (24 hours) slag moulds retain more or less similar mould properties with sand. Table 4 shows the mould properties with various combination of sand and salg mixtures after 24 hours duartion. Improved strengh properties with optmum permeability was obtained for higher slag content; it was further high for 50\% slag addition onwards. Above $20 \%$ slag addition, improved permeability values were noticed; and same values were continued even for more amount of 
slag presence. The reasons for above might be due to the combination of two kinds of mould ingredients with different particles morphology of spherical and angular for sand and slag respectively; these could have better interlocking between one another and also with the binders lead to enhanced mould properties (Heine et al., 2014).

Table 3: Shows the mould properties of $100 \%$ silica sand with the addition of $6 \%$ sodium silicate \& $1.5 \%$ Fe-Si powder; and $100 \%$ GBF Slag moulds with the addition of $10 \%$ sodium silicate \& $2 \%$ Fe-Si powder at various mould setting times.

\begin{tabular}{|c|c|c|c|c|c|c|c|c|c|c|c|c|c|c|}
\hline \multirow{2}{*}{ S. no } & \multirow{2}{*}{$\begin{array}{c}\text { Mould } \\
\text { Materials }\end{array}$} & \multirow{2}{*}{ Property } & \multicolumn{12}{|c|}{ Mould setting time, hours } \\
\hline & & & 1 & 2 & 4 & 6 & 8 & 10 & 12 & 14 & 16 & 18 & 20 & 24 \\
\hline \multirow{4}{*}{1.} & \multirow{4}{*}{ Sand } & Hardness & 90 & 96 & 98 & 98 & 98 & 98 & 98 & 98 & 98 & 98 & 98 & 98 \\
\hline & & $\begin{array}{l}\text { Dry } \\
\text { Compression } \\
\text { strength (psi) }\end{array}$ & 92 & 96 & 96 & 96 & 96 & 96 & 96 & 96 & 96 & 96 & 96 & 96 \\
\hline & & $\begin{array}{l}\text { Dry shear } \\
\text { strength (psi) }\end{array}$ & 55 & 75 & 75 & 75 & 75 & 75 & 75 & 75 & 75 & 75 & 75 & 75 \\
\hline & & $\begin{array}{l}\text { Permeability } \\
\text { number }\end{array}$ & 650 & 650 & 650 & 650 & 650 & 650 & 650 & 450 & 450 & 450 & 450 & 450 \\
\hline \multirow{4}{*}{2.} & \multirow{4}{*}{$\begin{array}{l}\text { GBF } \\
\text { Slag }\end{array}$} & Hardness & 90 & 90 & 96 & 96 & 96 & 96 & 96 & 98 & 98 & 98 & 98 & 98 \\
\hline & & $\begin{array}{l}\text { Dry } \\
\text { Compression } \\
\text { strength (psi) }\end{array}$ & 16 & 30 & 44 & 54 & 58 & 60 & 75 & 80 & 85 & 90 & 90 & 90 \\
\hline & & $\begin{array}{l}\text { Dry shear } \\
\text { strength (psi) }\end{array}$ & 10 & 29 & 43 & 55 & 65 & 70 & 70 & 70 & 70 & 70 & 75 & 75 \\
\hline & & $\begin{array}{l}\text { Permeability } \\
\text { number }\end{array}$ & 480 & 480 & 470 & 470 & 350 & 350 & 350 & 350 & 350 & 350 & 350 & 350 \\
\hline
\end{tabular}

Table 4: Shows the mould properties for various combinations of silica sand and GBF Slag with addition of $10 \%$ sodium silicate and $2 \% \mathrm{Fe}-\mathrm{Si}$ powder at 24 hours mould setting time.

\begin{tabular}{|c|l|c|c|c|c|}
\hline \multirow{2}{*}{ S. no } & \multicolumn{1}{|c|}{ Mould materials } & \multicolumn{4}{|c|}{ Mould properties } \\
\cline { 3 - 6 } & & $\begin{array}{c}\text { Hardness } \\
\text { number }\end{array}$ & $\begin{array}{c}\text { Dry Compression } \\
\text { strength (psi) }\end{array}$ & $\begin{array}{c}\text { Dry shear } \\
\text { strength (psi) }\end{array}$ & $\begin{array}{c}\text { Permeability } \\
\text { number }\end{array}$ \\
\hline 1. & $100 \%$ Sand & 96 & 85 & 63 & 320 \\
\hline 2. & $90 \%$ Sand +10\% GBF slag & 96 & 85 & 65 & 400 \\
\hline 3. & $80 \%$ Sand +20\% GBF slag & 96 & 90 & 69 & 400 \\
\hline 4. & $70 \%$ Sand +30\% GBF slag & 96 & 90 & 70 & 400 \\
\hline 5. & $60 \%$ Sand +40\% GBF slag & 90 & 90 & 70 & 400 \\
\hline 6. & $50 \%$ Sand +50\% GBF slag & 90 & 90 & 70 & 400 \\
\hline 7. & $40 \%$ Sand +60\% GBF slag & 88 & 90 & 70 & 400 \\
\hline 8. & $30 \%$ Sand +70\% GBF slag & 88 & 90 & 70 & 400 \\
\hline 9. & $20 \%$ Sand +80\% GBF slag & 88 & 90 & 70 & 400 \\
\hline 10. & $10 \%$ Sand +90\% GBF slag & 88 & 90 & 70 & 380 \\
\hline 11. & $100 \%$ GBF slag & 88 & 90 & 70 & 350 \\
\hline
\end{tabular}

\subsection{Melting and Casting Practice of A356 Aluminum alloy and Grey Cast Iron}

A display of the diverse stage of the preparation of mould is revealed in Figures 8-11. The figures, in addition reveals the procedure for casting as well as the cast products of A356 alloy and also the gray cast iron, correspondingly, of sand as well as GBF slag as mould materials. The figures obviously reveal that the composed sand as well as slag moulds has the most advantageous hardness of the mould while the mould cavities have accurate sizes and shapes. The standard metal casting practice was adopted by placing the runner and riser in the moulds. The molten metal was allowed in the preheated mould cavities via sprue, runner and gating system. Consistent and uninterrupted molten metal was filled in the mould cavities. The finished casting components of sand and slag have evident that very less amount of mould ingredients were stick to the casting surfaces. All these castings show good surface finish with no surface defects; these also reveal good dimensional accuracy. Further castings made 
with slag moulds with and without sand mixing shows cleaned surface finish on par with the sand castings. It has been observed that no mould walls collapse, neither dripping nor fusing of mould ingredients was occurred both in slag or sand moulds; this was evident for all the alloys under investigation. It could be perceived that $100 \%$ slag mould as the collapsibility of the mould was of high quality as of either sand or blend mould. Further after machining, no porosity or any other surface defects were noticed on all these castings. Finally a smooth surface, defects free and good dimensional accuracy castings were able to produce by these three moulds under investigation.

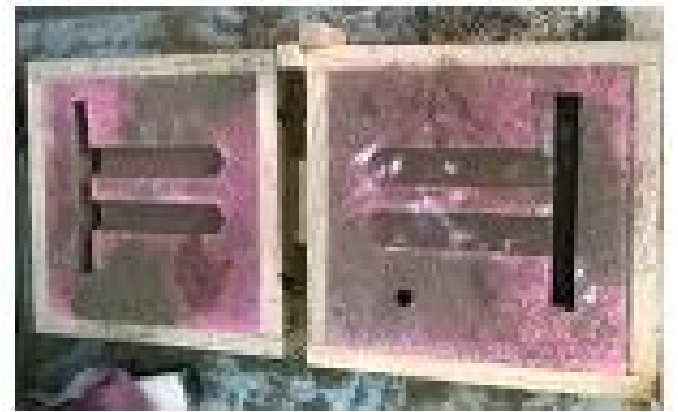

(a)

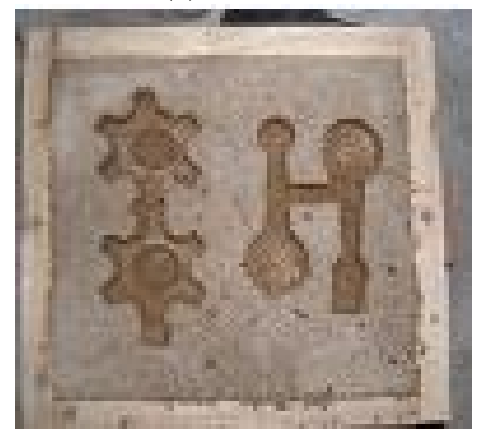

(c)

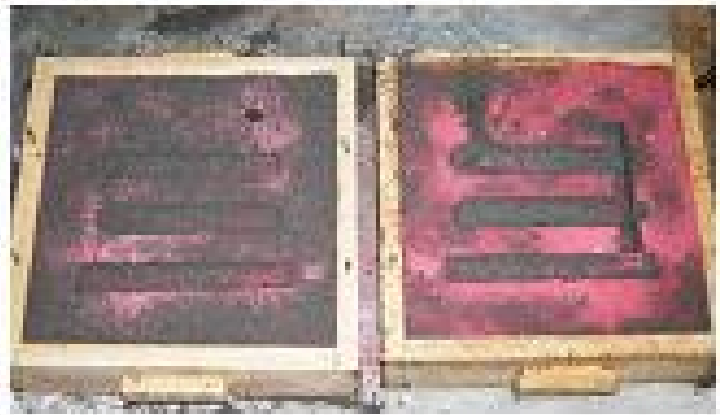

(b)

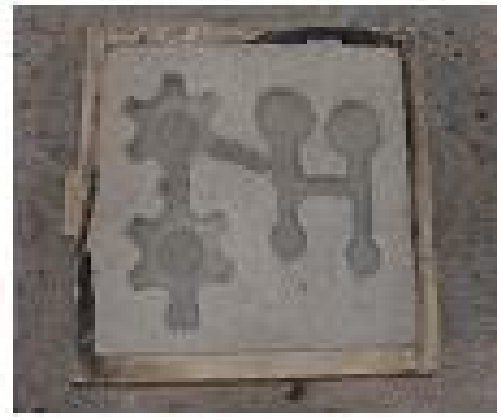

(d)

Figure 8: (a \& b) Silica sand GBF slag moulds respectively with cylindrical mould cavities (c \& d) Silica sand GBF slag moulds respectively with Gear wheel \& Connecting rod as mould cavities

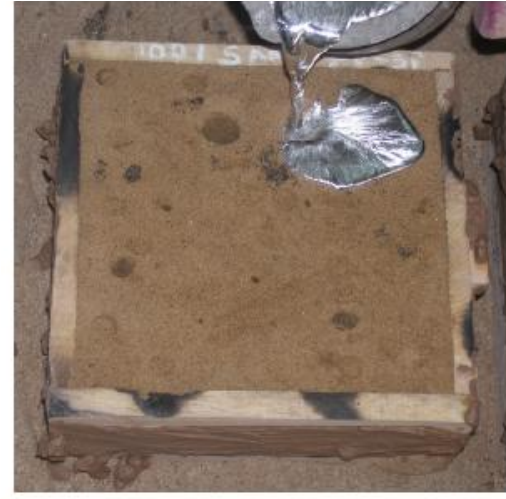

(a) Sand mould- A356 alloy

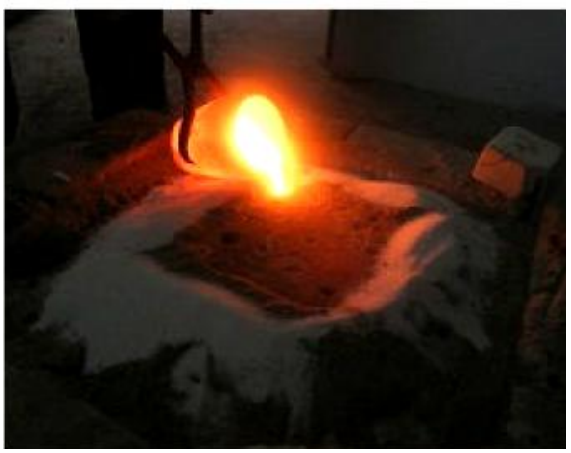

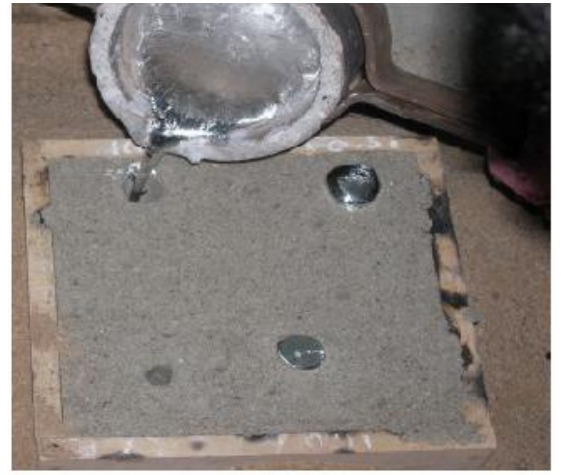

(b) GBF Slag mould- A356 alloy

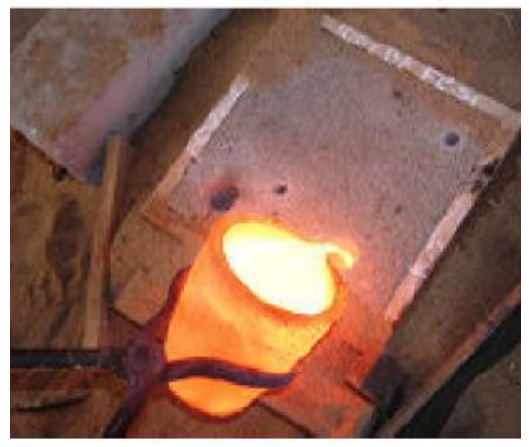


(c) Sand mould- Grey Cast Iron

(d) GBF Slag mould -Grey Cast Iron

Figure 9: Casting of : A 356 aluminium alloy (a \& b) and grey cast iron (c \&d) castings in Sand and GBF Slag moulds

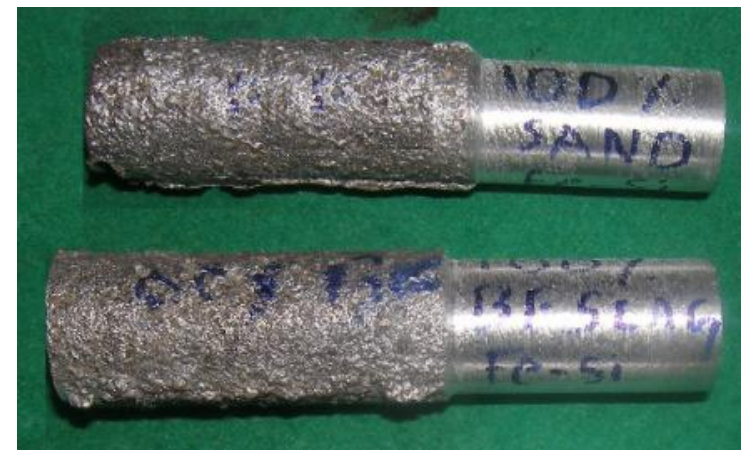

(a)

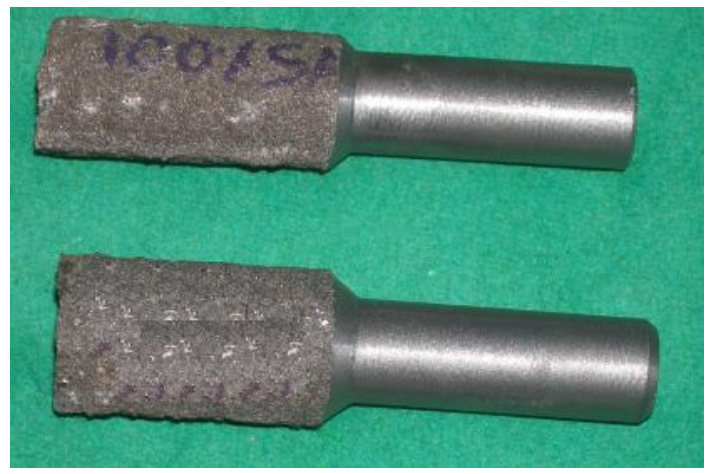

(b)

Figure 10: (a) A 356 alloy and (b) Grey Cast Iron cylindrical fingers before and after machining made by Sand and GBF Slag moulds

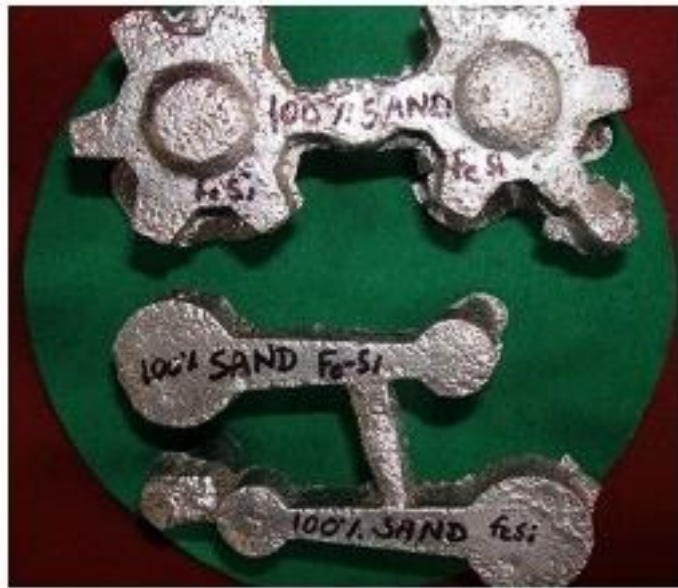

(a)

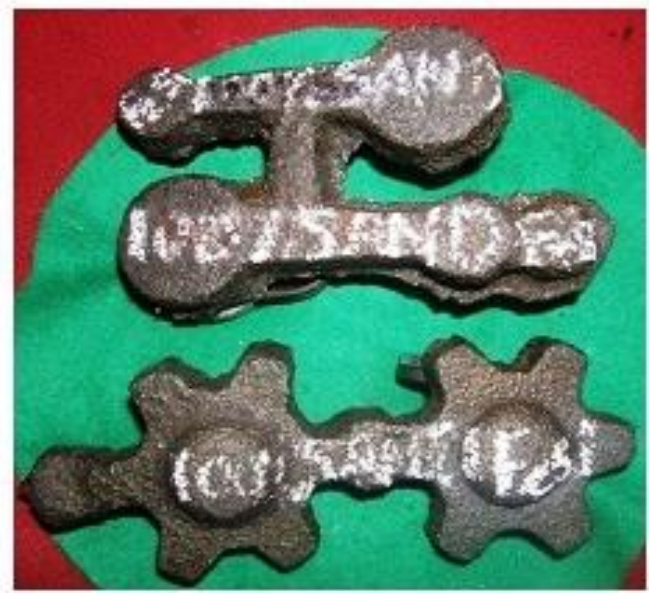

(c)

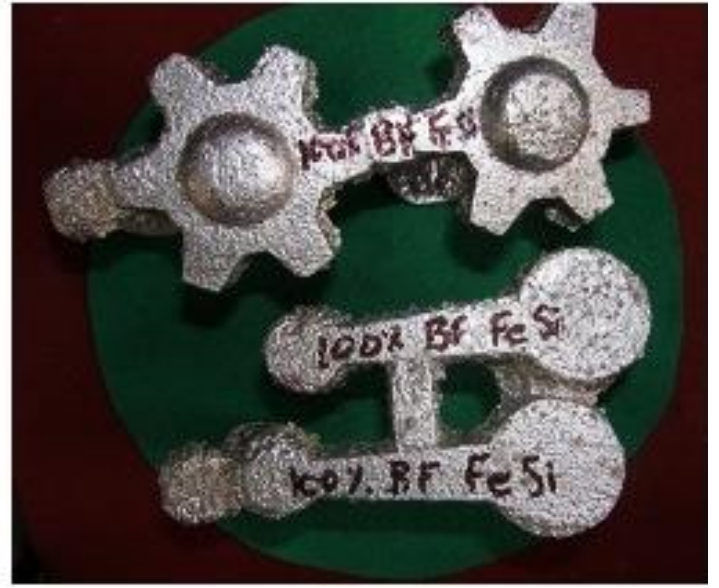

(b)

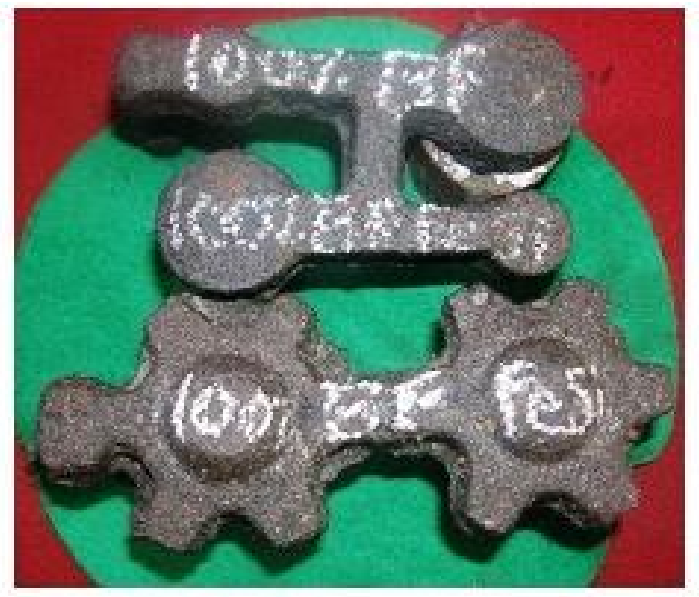

(d)

Figure 11: Cast products of Gear wheel and Connecting rods made in Sand and GBF slag moulds 


\section{Conclusions}

1. The obtained GBF slag moulding properties are on par with the silica sand. Optimum mould properties were retained even after 24 hrs duration.

2. SEM studies are shown a uniform binder coat was existed on both sand and GBF slag particles.

3. The composed sand as well as slag moulds has the most advantageous hardness of the mould while the mould cavities have accurate sizes and shapes

4. The ferrous as well as non-ferrous castings were run successfully. All these castings exhibits high quality surface finish devoid of defects on surfaces; these also reveal high quality accuracy in dimensions.

5. GBF slag could be employed in substitution to moulding sand in ferrous (cast irons) as well as non-ferrous castings.

\section{Acknowledgements}

Thanks to the DST -Fly Ash Unit - New Delhi, India to have supported us financially. The authors also show gratitude to the Department of Metallurgical Engineering, Andhra University College of Engineering, Visakhapatnam, India in their support for the essentials to carry out the experiments. Furthermore, a huge thanks to RINL, Visakhapatnam Steel Plant, Visakhapatnam, India that supplied the GBF slag used for this research.

\section{References}

Al-Jabri, K.S., Hisada, M., Al-Oraimi, S.K., Al-Saidy, A.H., 2009. Copper slag as sand replacement for high performance concrete. Journal of Cement and Concrete Research. Vol.31, pp.483- 488.

ASM Handbook- Casting, 2008, Volume - 15, ASM International.

Bo X, Zhengda X, Xiuping W, 1995. A new method for the investigation of binding properties of silicate-sand. Journal of Hubei Polytechnic University, Vol.10, pp. 6-9.

Dańko J., Kamińska J. \& Skrzyński M, 2013, Reclamation of spent moulding sands with inorganic binders in the vibratory reclaimer Regmas. Archives of Metallurgy and Materials. Vol. 58, No. 3, pp.993-996

Dash, M.K., Patro, S.K., Rath, A.K. 2016. Sustainable use of industrial-waste as partial replacement of fine aggregate for preparation of concrete, International Journal of Sustainable Built Environment, Vol. 5, No. 2, pp. 484-516.

Heine R, Loper C, Rosenthal P., 2014, Principles of Metal Casting, Tata McGraw Hill (India), $2^{\text {nd }}$ edition.

Kothai, P.S., Malathy, R., 2014. Utilization of steel slag in concrete as a partial replacement material for fine aggregates. International Journal of Innovative Research in Science, Engineering and Technology, Vol. 3, No.4, pp. 1585-1592.

LaFay V., 2015. Application of no-bake sodium silicate binder systems, International Journal of Metal Casting, AFS Transactions, Vol.6, No. 3, pp. 19-26.

Murthy I.N. and Rao J.B., 2016. Investigations on physical and chemical properties of high silica sand, Fe-Cr slag and blast furnace slag for foundry applications, Procedia Environmental Sciences, Vol. 35, pp. 583-596.

Stachowicz .M, Granat. K, Nowak. D, Haimann K, 2010. Effect of hardening methods of moulding sands with water glass on structure of bonding bridges, Archives of Foundry Engineering, Vol. 10, pp.123 - 128

Svyazhin A.G., Shakhapazov E. Kh., Romanovich D.A., 1998. Recycling of slags in ferrous metallurgy, Metallurgist, Vol. 42, pp. $129-132$.

\section{Biographical notes}

Prof. Babu Rao Jinugu, working as Professor and chairman- (Board of studies) in the Dept. of Metallurgical Engineering, AU College of Engineering, Andhra University, Visakhapatnam since May 2000. He completed his B. Tech and M. Tech in Metallurgical Engineering from NIT Warangal and Ph. D from Andhra University, Visakhapatnam. Prior to join in this University, he worked as Assistant Manager (QA \& TD), R\&D division of RINL, Visakhapatnam Steel Plant, and Visakhapatnam since Sept'1995-April 2000 and also worked as Scientist in C-MET Laboratories, Dept of Electronics, and Hyderabad for a period of two months (August - September 1995). He is the Life member for The Indian Institute of Metals (IIM) - Kolkata, Life Member for Tribology Society of India (TSI) and Life member for The Institution of Engineers (IEI). At present he is holding the positions of Joint Secretary - IIM Visakhapatnam Chapter, Chairman - IIM Visakhapatnam Students Chapter and Member- Editorial Board of IIM News Magazine. He is currently working on Studies on suitability of Industrial wastes of fly ash, Blast Furnace slag and Fe-Cr slag for foundry applications - 2013-2015 (File No. FAU / DST/ 600(52) /2012-13) by Dept of Science and Technology (DST), India and also worked for UGC, New Delhi sponsored Major Research Project (File No: 34 -396/2008 (SR) on "Synthesis and Characterization of Al-Fly Ash Nano Composites" and also working for one AICTE, New Delhi sponsored research project (File No: 1-51/FD/CA/ (19)2006-2007) on "Studies on cold workability limits of Aluminium and its alloys". He was chosen by AICTE-New Delhi as "Career Award for Young Teacher" in the year 2007. He was visited Beijing, China, Singapore and Sydney, Australia in the years 2008 and 2009 respectively for participation and presenting the papers at various international conferences. At present, a total of 116 research papers were published at various national and International journals/ 
conferences. His current areas of research are Nano Composite Materials, Metal Forming and Industrial Waste treatment for metallurgical applications

I Narasimha Murthy and N Arun Babu, working as Ph. D research scholars in the Department of Metallurgical Engineering, Andhra University, Visakhapatnam, India under the supervision of Prof. Babu Rao Jinugu.

Received June 2017

Accepted December 2017

Final acceptance in revised form January 2018 